\title{
The role of external protective factors on young entrepreneurs`entrepreneurial resilience: an explorative study
}

\begin{abstract}
To receive support is crucial among youth in order for them to achieve success in life as it could hinder social exclusion, especially for at-risk young people. Empowering the potentials of at-risk youth through the support of external protective factors may enhance and optimise their potency. This study explores the role of external protective factors in young entrepreneurs' resilient development. This research is based on the hematic analysis of semistructured interviews with five graduates from Baitulmal Skills Institution who are recognized by the Institution as successful entrepreneurs. This research has found four thematic external protective factors, which contributed to young entrepreneurs' resilient development; namely getting support from educational institutions, good rapport with peers, supportive teaching staffs, youth-adult attachment and support in business management. The role of external protective factors in developing young entrepreneurs' entrepreneurial resilience heavily relies on youth's positive interaction with his/her environment. It is suggested that in the future, studies should focus on protective factors that concentrate on other types of at-risk youth who are able to develop positively.
\end{abstract}

Keyword: Youth development; Resiliency; Protective factor; Entrepreneurship 